\title{
AN EMPIRICAL ASSESSMENT OF A LEARNING AND KNOWLEDGE MANAGEMENT TYPOLOGY FOR RESEARCH JOINT VENTURES
}

IE Working Paper

DO8-114-I

19 / 04 / 2004

Elena Revilla

Juan Acosta

Professor of Operation Management

Instituto de Empresa

María de Molina, 12, 5.

28006, Madrid

Spain

elena.revilla@ie.edu

\author{
Universidad de La Laguna \\ Santa Cruz de Tenerife \\ Spain \\ Jacosta@ull.es
}

\begin{abstract}
As innovation and technology management grow in complexity the need for inter-organizational cooperation increases. Part of this coop eration requires the understanding of how knowledge management and learning processes may function to support a successful research and development collaboration. To further this understanding we introduce a typology to help categorize various collaborati ve efforts within a research joint venture environment. The typology is based on two dimensions the locus of the research joint venture knowledge and the knowledge management approach. Using a broad -based European database 98 research joint venture projects were used to evaluate the typology. We test two hypotheses related to these relationships. Implications for research and management of these types of projects are also introduced throughout the paper.
\end{abstract}





\section{INTRODUCTION}

Innovation and innovation capacities are necessary elements to manage and thrive in an environment with increased global competitiveness and highly dynamic markets. Over the last couple of decades, corporate emphasis on innovation has stemmed from such pressures as shortened lead times, mass customization, and the growth of technological advances. Organizations that institutionalize innovation and adopt an open attitude to change are better positioned in this type of market.

We view new knowledge (especially technological knowledge) as the foundation for innovation, change, and sustainable competitive advantage. The primary role of research and development (R\&D) within organizations is to create new knowledge or recombine existing knowledge to create new innovations. Roussel et al. (1995) suggest that the only real product of R\&D is knowledge. Thus, the R\&D process is knowledge-intensive, it not only uses existing knowledge but also creates new knowledge, which provides competitive advantage to the firm.

Historically, firms organized R\&D internally and relied on outside contract research only for relatively simple functions or products (Mowery, 1983; Nelson, 1990). From this point of view, firms adhered to the following philosophy: Successful innovation requires control. Chesbrough (2003) expresses this idea stating that companies must generate their own ideas that they then develope, manufacture, market, distribute and service themselves. Today, in many industries, global competition, product and process complexity, along with technological advances, has made obsolete this of an internally oriented approach to $\mathrm{R} \& \mathrm{D}$ and forcing firms to rethink methods for new knowledge acquisition.

During the last few years, useful knowledge beyond the organizational boundary has become widespread, thus companies should not restrict their knowledge attainment only to what was developed in their internal research. For R\&D to succeed, knowledge should be collected from all critical sources. This situation has made companies explore innovative ways that embrace and integrate external knowledge in conjunction with internal $R \& D$. Thus in recent decades there has been unprecedented growth in $R \& D$ joint ventures (RJVs) in order to expand firms' knowledge. Beyond competitive reasons other explanations to this growth include greater government support and industrial policy, and relaxed regulatory policies. RJVs are seen as mechanisms enabling firms to learn and enter new technological areas and to deal more effectively with technological and market uncertainty. However, the success of this strategy in the long term depends on the proper integration of knowledge developed during the R\&D process.

In order to effectively interact with the external environment and integrate knowledge, RJVs need to manage knowledge and its related processes. Because knowledge is a critical output of learning, successfully managing the learning process inherently involves the effective management of knowledge. Managing knowledge requires the introduction of criteria to decide which knowledge factor is most critical for the organization and to govern these factors and conditions to guide the activities of knowledge acquisition (DiBella and Nevis, 1996). Thus, knowledge management and 
the knowledge-based view of the firm have become a central theme in innovation and R\&D. Some scholars believe that competition is becoming more knowledge-based and that the sources of competitive advantage are shifting to intellectual capabilities away from physical assets (Subramanian and Venkatraman, 1999). Given that knowledge management is recognized as a critical and central practice in $R \& D$, managers and researchers have lacked management models that could be used as guides in this environment. With an absence of good conceptual models, understanding the effectiveness of knowledge management practices in RJVs is still a difficult task. Research in this area is still at an early stage of defining the contexts of knowledge integration. Empirical studies that validate sound conceptual models of knowledge management in R\&D are still rare (Pisano, 1994; Grant, 1996; Johannessen, et al., 1999; Hoopes and Postrel, 1999). The main cause of the limitation of progress in developing a linkage is the lack of data and the unobservable nature of certain key variables highlighted in the theoretical literature. Even methods that are more refined quantitatively, are not perfect solutions (Luukkonen, 1998).

In light of this situation RJVs increasingly demand frameworks to manage the knowledge developed from their R\&D activities. In this paper, we use contingency theory to examine the proposition that the characteristics of a RJV's knowledge base, integrated in the concept of the locus of the RJV, has an important influence on its knowledge management choice. Traditionally, contingency theory has focused on such contingency variables as environmental uncertainty, firm size, and firm technology. Our approach is built on recent advances in knowledge management to establish whether the locus of the RJV, which refers to the stage of technical development at which the RJV operates, can be considered a useful contingency variable in its own right.

In order to reach this goal, we began with evaluating the many different conceptualizations of knowledge management. Essentially, the published research has these conceptualizations summarized according to two different perspectives (Daft and Huber, 1987; Mirvis, 1996; Garavan, 1997; Gnyawalli and Stewart, 1999; Hansen et al 1999; Prieto, 2003): the techno-structural perspective and the behavioral perspective. Other studies have examined the key knowledge characteristics and pointed out their influence on the management of the firm's activities related to acquisition of knowledge (Grantt, 1996). Organizational learning has identified different types of knowledge for the locus of an RJV. In our analysis of the above concepts, we suggest that knowledge management should be consistent with the particular locus of the RJV.

Thus, the core purpose and contribution of this paper is to determine if differences in knowledge management are dependent on the locus of the RJV. In order to do this, we will classify RJVs based on two dimensions, locus of the RJV and the knowledge management orientation. Each of these dimensions and their theoretical constructs are described and later integrated in this research framework. An initial evaluation of this relationship is completed using information and practices from data acquired from a broad-based study of European-based RJVs. As part of this effort, differences in knowledge management and the locus of the RJVs are empirically analyzed. Initially, before discussing the dimensions in detail, an overview of RJV knowledge creating and transfer processes is presented. We view this background as fundamentally important to the later dimensional discussions. 


\section{RESEARCH JoINT VENTURES, LEARNING AND KNOWLEDGE MANAGEMENT}

The prime motivations for creating a RJV is to access knowledge, which is not yet widely distributed or exploited (Zack, 1999), providing learning opportunities, and the potential for value creation. Thus, we define an RJV as a collaborative agreement in which two or more partner organizations (firms and/or public research organizations) decide to coordinate their R\&D activities through a cooperative project and to share the knowledge generated from this joint effort. In ideal situations, partners bring their own knowledge, learned throughout their histories in the form of technology, people or processes, to the newly created project in the hope that this combination of knowledge will produce benefits for all those concerned. This definition of RJV is similar to the recently used by the Council on Competitiveness (1996) where "partnerships are defined as cooperative arrangements engaging companies, universities, and government agencies and laboratories in various combinations to pool resources in pursuit of a shared R\&D objective".

By bringing together firms with different knowledge bases an RJV creates unique learning opportunities for the partners (Inkpen, 1998). Learning for partners requires connecting people so they can think together, creating environments in which complex knowledge can be interpreted and leveraged (McDermott, 1999). This learning will happen only when R\&D managers, scientists, and engineers feel comfortable sharing knowledge with their counterparts in other organizations. In the presence of organizational and national boundaries across which knowledge flows this can be particularly challenging (Berdrow et al., 2003). Differences in language, norms and mental models often inhibit personal interactions, interactions that are critical to creating a learning environment for RJVs. Unless the RJV makes deliberate efforts, knowledge generated by a partner remains with the partner. For RJVs to innovate rapidly, it is imperative to make deliberate efforts to manage R\&D knowledge. In this respect, an understanding of the acquisition of knowledge for RJVs could benefit RJV managers.

The literature on knowledge management distinguishes two core processes in the acquisition of knowledge for RJVs: (1) the creation of new knowledge through interaction among organizations and (2) the transfer of the existing knowledge from one organization to another (Larsson et al. 1998). Thus, the question confronting us now is how the individual partners must act to create this collective knowledge -the knowledge creating process- and how the RJV knowledge can be transferred to their own organization -the knowledge transfer process.

\subsection{The knowledge creating process}

The target of a process for knowledge creation is to enhance the potential of creating innovations (Von Krogh et al, 2001) as part of an adaptive behavior to be able to respond to environmental demands. Many researchers have come to the conclusion that 
solving problems creates knowledge (see Jaikumar and Bohn (1986); Hayes et al. (1988) and Perez Lopez (1991)). This conclusion implies that a RJV may recognize and define problems, generate and applie knowledge to solve problems, and further generate new knowledge through the action of problem solving (Nonaka, et al., 2000). By knowledge creation through problem solving, a RJV refines the understanding of its environment, increases its absorptive capability and improves its ability to react appropriately to future stimulus.

The creation of knowledge by an RJV is not just an agglomeration of devices to gain access to an individual firms' knowledge. It should be more than a collection of individual experiences. Senge (1990) considers that for learning to take place at a group level, an alignment of the different individual learning processes is necessary in order to avoid wasted energy. From an organizational learning perspective, it requires a high degree of mutual involvement in problem recognition and problem solving processes. In the first step, partners must scan, notice and construct meaning about environmental changes. The recognition of the existence of a problem occurs when some stimuli indicate the need for new actions. These stimuli then lead to the second step, when partners jointly experience new work processes, tasks, technological characteristics etc. to solve a problem.

Von Krogh et al. (2001) propose an iterative and multistage process for knowledge creation that obligate partners to spend considerable time together, discuss, and reflect upon their experiences, observe how their colleagues solve tasks and interact with technologies, explain, and give sense to their own actions. RJV members must establish relationships via language and thought in order to coordinate their learning processes.

Dialogue (Isaacs, 1993) has been identified as a key aspect of this integrating process ${ }^{1}$. Each partner exhibits a perception or personal image of the world, and these perceptions will affect the other firms when they are shared during interaction. Individual knowledge needs to be disclosed, shared and legitimized until it becomes part of group knowledge. RJV knowledge is the result of the construction and interaction of numerous individual firm perspectives during problem recognition and problem solving processes.

\subsection{The knowledge transfer process}

The knowledge creating process that happens in the RJV does not guarantee that individual partners benefit from such knowledge on a larger scale. At this point, the problem an organization faces is transferring RJV knowledge to individual organizations. For this transfer to take place, it is essential that RJV knowledge is introduced and materialized in the operational systems of the organization, improving its activities.

Although RJV is a means through which firms learn, the created knowledge needs to be communicated and integrated into its organizational routines in order to influence

\footnotetext{
${ }^{1}$ The dialogue has been called "the language of learning" (Nonaka and Takeuchi, 1995; Bechtold, 2000),
} 
organizational effectiveness. An individual organization learns by changing its actual routines (Argyris and Shön, 1978). The intangible nature of knowledge assets prevents knowledge from being completely diffused and subsequently used in the organization, unless "mental models" are simultaneously transferred. Changes in organizational routines and decision rules will not likely take place if mental models are not shared by members (Kim, 1993). Thus, the extent to which these mental models are shared determine their understanding of the problem, fostering its diffusion and facilitating its materialization.

Cohen and Levinthal (1990) and Lane et al. (2001) express this idea in terms of "absorptive capacity" which expresses the firm's ability to assimilate new knowledge and make use of the benefits of joint research. Absorptive capacity contributes to innovation because it tends to develop cumulatively and builds on prior related knowledge. Given the intense cumulative nature of scientific knowledge, the firm's knowledge prior to an RJV influences the effective acquisition and utilization of new knowledge. As Powell et al. (1996) argued, knowledge facilitates the use of other knowledge. What can be learned is affected by what is already known. Organizations that possess relevant prior knowledge are likely to have a better understanding of the new knowledge, can generate new ideas and develop new products. Organizations with a high level of absorptive capacity are likely to harness new knowledge from an RJV to help their innovative activities. Without such capacity, they cannot learn or transfer knowledge from the RJV.

\section{The locus of the RJV}

As previously stated, RJVs can not be conceptualized as mere exchange relationships involving the transfer of products or services. A RJV differs from others kinds of collaboration in that primary motivation for joining a RJV is to gain new knowledge which can be processed and transformed into a competitive asset. Underlying the RJV is the attempt to increase the knowledge base of the organization through a cooperative $\mathrm{R} \& \mathrm{D}$ project.

One of the most widespread elements that influence on the RJV's knowledge management are the characteristics of the knowledge to be developed by the R\&D process (Winter, 1987). We do not concentrate in separate knowledge characteristics in this paper but as an integrated concept within the general characteristic of locus of the RJV.

Thus, to investigate RJV knowledge management, we begin by defining the "locus of the RJV" which refers to the stage of technical development at which the RJV operates. The main stages of technical development are: (1) basic research which searches for new concepts or scientific principles, although they may not present any direct application; and (2) applied research which utilizes acquired knowledge from basic research, showing its potential practical contributions to solve known problems. This characterization of basic and applied research is arguably more conceptual than practical, given the considerable gray area between these two extremes of the R\&D continuum. 
In terms of knowledge, these two stages involve different levels of "radicalness" of its learning process ${ }^{2}$. While applied research focuses on knowledge development from an existing body of knowledge, basic research seeks to construct and acquire new knowledge, adding to the body of knowledge. Viewed broadly, technological change occurs in two extreme forms. In the first situation, the developing knowledge comes from the existing knowledge. In the second situation new knowledge is created with loose connections to existing knowledge.

The locus of the RJV can be seen as an important categorization of knowledge assets. Organizational learning has suggested different dimensions of knowledge to understand the locus of the RJV. Yet, there has been little consistency in classifying knowledge ${ }^{3}$. Our focus is on categorizing the intrinsic nature of knowledge associated with RJVs related to the ease of knowledge creation and transfer. The following three dimensions are chosen: tacit-explicit, generic-specific and autonomous-systemic. These dimensions should not be viewed as dichotomous (i.e. one must fall into one group or another within a given dimension) but rather as a spectrum with two extreme knowledge types at either end.

The tacit-explicit dimension. Polanyi (1967) distinguishes between tacit and explicit knowledge. This categorization can be thought of as the difference between experiential and articulated knowledge (Simonin, 1999). Explicit knowledge consists of knowledge that can be expressed in symbols and can be communicated through these symbols to other people. Tacit knowledge is difficult to express and communicate to other people because it cannot be codified and articulated. Therefore, tacit knowledge is difficult to pass to others outside the community-of-practice because they will not understand the terminology and basic principles associated with it. In fact, explicit knowledge is revealed by its communication while tacit knowledge is revealed through its application (Spencer and Grant, 1996). Tacit knowledge, accumulated through experience, is often referred to as "learning by doing". According to this categorization, we expect that the more scientific, and basic, the RJV R\&D project the more explicit the knowledge.

The generic-specific dimension. This concept is related to what other authors have referred as universal versus localized knowledge (Bonaccorsi and Piccaluga, 1994). Following these authors we define generic knowledge as the scope of its application to various target problem domains, even different from the source domain. Under this respect, generic knowledge is highly universal as opposed to specific knowledge that can only be used within its source domain.

Specific knowledge is more easily appropriated than generic knowledge, even when generic knowledge can be more readily codified. Despite this fact an RJV may have no other option than to look for scientific knowledge when local solutions to specific problems are ineffective or too costly to develop. Generic knowledge, especially intense

\footnotetext{
${ }^{2}$ This concept is related to innovation radicalness, which has been discussed by others (e.g. Tushman and Anderson, 1986).

${ }^{3}$ Learning classifications can be found on Winter (1987); Badaracco (1991; Chesbrough and Teece (1996); Collins (1993).
} 
in basic research projects and at the beginning of the development of the knowledge field, may eventually result in dramatic productivity increases and cost reduction in activity design (e.g. algorithms for parallel computing, new design tools, simulation techniques and so on), but may be less useful than specific knowledge for the organization. Global time-based competition and a reduced product life cycle do not allow RJVs to fully market and exploit basic research output making such research a risky undertaking. The more generic the knowledge is the more it is capable of producing broad and indiscriminate benefits and providing impetus for future advances in knowledge. We can categorize generic knowledge as more characteristic of basic research while specific knowledge is at the applied research locus.

The systemic-autonomous dimension. This dimension is related to Henderson and Clark's (1990) classification of component and architectural knowledge. It expresses the dependency of the knowledge development process from other innovations or organizational processes. The fewer the functions or knowledge areas that are involved in the R\&D project, the more autonomous it is and the further away it usually is from the expected market. Thus, basic research can be implemented as an autonomous process. On the other hand, applied research requires strong feedback between technological users, suppliers, and producers thus increasing the project organizational dependency between the diverse functional knowledge areas involved in the R\&D project.

Autonomous knowledge can exist independently whereas systemic knowledge cannot or should not be decomposed into independent parts. Because systemic knowledge is typically held organization-wide it is collective in nature. Moreover, since it is difficult for any one person to understand the whole system, it is typically tacit.

The dimensions of knowledge that we have described facilitate understanding of the knowledge associated to the locus of the RJV. We can argue that basic research tends to be more explicit, generic, autonomous and generally a creator of new knowledge, while applied research that focuses on existing knowledge tends to be more tacit, specified, systemic and more a transfer mechanism of knowledge.

\section{Knowledge management perspectives}

In the previous section we presented some characteristics of RJV R\&D characteristics based upon the locus of the RJV research. Now we focus on our second major typological dimension, knowledge management characteristics. Knowledge management aims to govern the factors that influence the acquisition of knowledge for RJVs. Knowledge management guides the evolution of the organizational knowledge asset. Considering that the most important source of a firm's sustainable competitive advantage resides in its knowledge assets and its capacity to increase them, an adequate functioning of this learning process is paramount to the preservation of a firm's competitiveness.

Although there are many organizational knowledge management dimensions, published research has often summarized them according to two different perspectives (Daft and 
Huber, 1987; Mirvis, 1996; Garavan, 1997; Gnyawalli and Stewart, 1999; Hansen et al 1999; Prieto, 2003): the techno-structural perspective and the behavioral perspective. These perspectives are founded on very different theoretical assumptions. The technostructural vision of knowledge management emerges from the positivist epistemology about learning development in organizations, which is an eminently "mechanic" point of view. The behavioral approach is a result of the constructionist epistemology, which highlight the human, social and interactive interventions of knowledge management. Table 1 shows the main arguments of each one of these perspectives that we subsequently describe.

Table 1. Main perspectives about learning development in organizations

\begin{tabular}{|c|c|}
\hline $\begin{array}{c}\text { TECHNO- } \\
\text { STRUCTURALPERSPECTIVE }\end{array}$ & IOURA \\
\hline $\begin{array}{l}\text { The environment is concrete and } \\
\text { objective and events are comprehensible } \\
\text { through information processing }\end{array}$ & $\begin{array}{l}\text { - The environment is equivocal and only } \\
\text { comprehensible when organizational } \\
\text { actors enact a common interpretive } \\
\text { framework }\end{array}$ \\
\hline - Understanding leads to action & - Action leads to understanding \\
\hline $\begin{array}{l}\text { The primary goal is to overcome } \\
\text { ignorance through rigorous information } \\
\text { gathering and analysis }\end{array}$ & $\begin{array}{l}\text { - The primary goal is to create and } \\
\text { communicate meanings by discussing } \\
\text { interpretations and confronting the } \\
\text { unknown with action }\end{array}$ \\
\hline $\begin{array}{l}\text { Knowledge management initiatives } \\
\text { are aimed to collect information about } \\
\text { particular problems, analyze them and to } \\
\text { structure it into concise formats that will } \\
\text { be conducive to action }\end{array}$ & $\begin{array}{l}\text { Knowledge man } \\
\text { aimed to enact and } t \\
\text { interpretations, to ta } \\
\text { to quickly redirect } \mathrm{e}\end{array}$ \\
\hline $\begin{array}{l}\text { - Huber (1991), March and Simon } \\
\text { (1993), McDonald (1995), Daft and Huber } \\
\text { (1987) }\end{array}$ & $\begin{array}{l}\text { - Weick (1979), Brown } \\
\text { (1991), Nonaka (1994), D } \\
\text { (1987) }\end{array}$ \\
\hline
\end{tabular}

The techno-structural perspective suggests knowledge is objective, static, universal and representative of a given external reality that includes objects and events. Accordingly, knowledge management is aimed to represent and reproduce that reality as closely as possible. It is accepted that objective information exists and must be rationally acquired, diffused and processed between organizational members by implementing and using tangible systems and elements. These systems must comprise the scanning, coordination and control mechanisms necessary to fit environmental contingencies and to reduce the uncertainty of a variety of potential actions (Daft and Lengel, 1986; Daft and Huber, 1987; March and Simon, 1993). 
From this point of view, knowledge management is synonymous with the design and employment of technical and structural procedures focused on work processes and information processing. Previous research defines the exchange of information and organization of collaborations as a means for facilitating the integration of R\&D. Bonacorsi and Piccaluga (1996) consider information exchange critical in any research activity and identify three dimensions of information exchange that determine the efficiency of the learning process: intensity and frequency of communication between partners; the communication media used for information exchange; and the spatial dimension of information exchange.

The behavioral perspective proposes that knowledge often remains in the human mind, related to feelings and experiences. Knowledge is subjective, dynamic, context specific and embedded in action. As a result, individuals can construct their own reality and modify those constructions on the basis of experience and even context characteristics.

Within this point of view, the primary goal of knowledge management is to analyze and enhance how individuals comprehend events until creating a common understanding as a basis for action. The literature in this area (Weick, 1979; Brown and Duguid, 1991, 1998; Schein, 1993; Hedlund, 1994; Nonaka, 1994) has stated that the potential of organizational members to discern the environment, interpret it and comprehend it is a social result because knowledge is social and has synergetic attributes. Thus, human behaviors should be aligned towards learning through the adjustment of conditions to develop the human potential. Specifically, we are referring to conditions such as transparency, communication, trust, creativity, responsibility, commitment and initiative.

Both perspectives provide different descriptions about the process of knowledge acquisition. As a consequence, knowledge management initiatives are also different. However, each of these perspectives has limitations that have induced their evolution towards integrative perspectives intended to create a general framework about knowledge management in organizations (Brown and Eisenhardt, 1997; Van der Krogt, 1998; Popper and Lipshitz, 1998, 2000; Choi and Lee, 2001). The integrative idea is to advocates that the techno-structural tools required for work performance as well as for the conditions of the human potential are required to adapt individuals' behavior. Thus, knowledge management in organizations is encouraged by 1) information mechanisms and coordination systems focused on the processing and analysis of information and 2) the personal, social or cultural values which are focused on the development of the human potential as well as on the creation of a shared meaning within organizations. The aim is that organizational members will be able to expand their competencies in agreement with the systems established to optimally work in organizations.

As a natural extension of how firms manage knowledge, an RJV may not take a uniform approach. Both transfer and creation knowledge types require simultaneous structural and human aspects. The behavioral approach of knowledge management focuses on the processes of collective language development and joint understanding, without which tacit knowledge is not created or disclosed and thereby cannot be received by the others 
or used collectively. The structural approach emphasizes the acquisition and distribution of the needed information to absorb the disclosed or generated knowledge.

RJV knowledge acquisition is therefore a joint outcome of the interacting organizations' choices and abilities to acquire and absorb information - the techno-structural perspective- and understand and use that information on the creation of new knowledge - the behavioral perspective. Given that this dual perspective is central to knowledge management literature, we make an axiomatic definition of these two approaches. These dimensions should not be viewed as dichotomous but rather as a continuum with the two knowledge management perspectives at either end.

\subsection{Hypothesis development}

We are now in position to develop specific hypotheses for empirical testing. Two hypotheses are put forward relating the locus of the RJV to knowledge management.

Basic research tends to be more explicit, generic and autonomous. The core argument here is that the more explicit the knowledge is the more easily it is expressed and communicated -either to another individual in the same firm or to other firm-. Explicitness makes means that the creation and transfer of explicit knowledge is relatively easy to accomplish via written documents, frequently supported by computer information systems. In these cases the knowledge exchange is achieved quickly articulating a common language, so the level of interpersonal interaction between $R \& D$ units can be lower.

Generic knowledge is intense in basic research. Since generic knowledge searches for general laws, the more generic the knowledge is, the higher the propensity of RJVs to develop well-established procedures that are relatively easily replicated in different settings. Over time, generic knowledge becomes specific and basic research becomes applied research.

Finally, basic research is autonomous. The autonomous category presupposes independent consciousness that will have a negative correlation with knowledge integration. Codified as a set of notes or a laboratory notebook, it is potentially available to others.

These arguments lead to the first hypothesis:

H1: RJVs that develop basic research, whose output tend to be more explicit, generic and autonomous knowledge, will manage their R\&D activities more according to a techno-structural approach than a behavioral approach.

Applied research tends to be more tacit, specific and systemic. Analyzing the tacitexplicit dimension, the acquisition of tacit knowledge requires factors such as intuition, spontaneity and values or beliefs associated with human development. The higher the level of tacitness of the knowledge involved in the RJV, the higher the frequency and intensity of information exchange through personal channels. In these cases, the 
knowledge will not flow easily between locations and the implementation of joint research activities is more necessary.

Specific knowledge emerges over time in a process of coevolution with the context in which it is embedded. Because of this, specific knowledge can not mean collecting individuals' answers to explicit questions about their behaviors. Applied research is more sensitive to its social and physical context than basic research. In order to be successfully communicated, specific knowledge needs to be personalized and distributed to meet specific needs. So, managers should be careful not to generalize knowledge and not abuse established procedures.

According to the categorization of systemic, applied research is best develop in a dedicated physical infrastructure shared among partners. All relevant research activities are nearby, encouraging the spontaneous exchange of knowledge. In these situations, formal and structural mechanisms have encountered some difficulties and knowledge management encourages close contacts among individuals.

Thus, we argue that:

H2: RJVs that develop applied research, whose output tend to be a more tacit, specified and systemic knowledge, will manage their $R \& D$ activities more according to a behavioral approach than a techno-structural approach.

\section{A TWO-DIMENSIONAL TAXONOMY OF RJV KNOWLEDGE RELATIONSHIPS}

Our study examines the interaction between the locus of the RJV -the contingency variable- and the means used by RJVs to manage their R\&D activities and share the different types of knowledge generated from this joint effort, and then, hypothesize the characteristics of the interaction. A focus solely on content of RJVs based R\&D process ignores the complex cognitive and behavioral changes that must occur before knowledge "outcome" can be identified (Inkpen and Dinur, 1998).

It is possible to define two critical dimensions that permit us to present a more suitable taxonomy of RJVs. These dimensions are summarized in Figure 1. The first dimension the locus of the RJV integrates different characteristics of knowledge and is focused on the stage of applied research at which the RJV operates. This vertical axis clearly delineates $R \& D$ projects that use existing knowledge, which is more tacit, specific and systemic, to solve problems and projects that generate new rules and knowledge, more explicit, generic and autonomous, to deal with a new problem. The second dimension, along the horizontal axis, is the knowledge management approach that supports the inter-organizational process of knowledge acquisition. The horizontal axis measures the extent to which the RJV focuses more on techno-structural practices versus behavioral practices to create and transfer knowledge. 
Figure 1. A typology of RJV knowledge management characteristics.

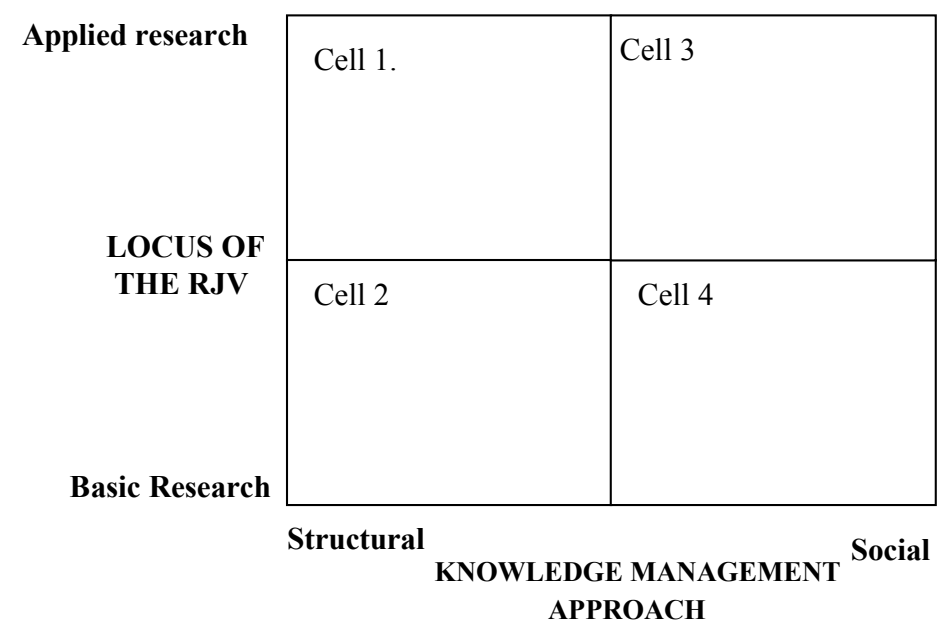

It is posited that RJVs placed in cell 1 on our two dimensional grid, develop R\&D projects that are focused on existing knowledge and manage the learning process in a structured way. Knowledge management basically lies in tangible structures and procedures that efficiently capture and retain the learning of the project and disseminate it to the partner organizations. In this cell $R \& D$ projects are oriented towards achieving efficiency in operations as well as reducing risk in operations. It increases the organizational capability of maintaining an organization's competitiveness with their current task and markets. In this situation, knowledge transfer, rather than knowledge creation, is essential to the consolidation of activities and competencies.

In terms of knowledge management, cell 2 shows a similar situation. These types of RJVs support the building of new knowledge but with a focus not so much on creating knowledge but on capturing and transferring knowledge from the RJV to the partners. The new knowledge is structured and applied according to existing processes. Because the new knowledge in this classification does not pre-exist within the firm, the key challenge is to effectively absorb the new knowledge. These RJVs aim at developing future competitive advantages and thereby enhancing the internal capability to face future changes. In the short term, the benefits are rarely appreciable.

Cell 3 defines RJVs that increase the scope and depth of existing knowledge by socializing members around certain problems, task, and work processes. Knowledge gaps between the members indicate the need to seek new insights, and invest time and energy. Since developing knowledge requires existing experience and knowledge, RJVs build up competencies and skill that, locally applied, generate a better understanding of the key processes or variants of existing products.

Finally, cell 4 includes RJVs that seek the biggest competitive advance. They develop $R \& D$ projects that seek to construct and acquire new knowledge and manage the learning process with a behavioral approach, based on innovation, creativity and trust. Here knowledge creation is something different when compared with the cell 3 . In this 
situation there is no available knowledge where you can judge the relevance for further expansion. In some ways, these RJVs become "corporate revolutionaries" that, with an entrepreneurial behavior, create knowledge that can become imperative to long-term performance. Although creating new knowledge is always risky because it breaks the existing coherence between the new knowledge and the prior knowledge, it produces the biggest level of learning, which sometimes changes the definition of a whole market segment.

According to our hypothesis and given this initial typology we speculate that most RJVs will be placed along the diagonal that join the cell 2 and cell 3 . Next, we'll evaluate empirical data from actual RJVs to determine how well our hypothesis can be tested.

\section{EMPIRICAL EVALUTION OF TYPOLOGY}

\subsection{Data collection and sample characteristics}

Data for this study have been drawn from a survey of over 240 European firms located in France, Greece, Ireland, Italy, Spain, Sweden and the United Kingdom, involved in cooperative research projects ${ }^{4}$ formed between 1990 and 1999. The analysis of these RJVs is based on two data sources. Firstly, an administrative database that supplied information on firms that participate in the RJV and their R\&D projects. After the analysis of this information, a questionnaire was designed to gather additional qualitative and perceptual information that form a more complete picture of the dynamism of these RJVs. The survey instrument was sent to the coordinator firm's manager responsible for the RJV. A company-based approach was adopted since the aim was to understand the knowledge and competencies created by each individual partner rather than for the R\&D consortium as a whole.

In this paper, we have only chosen the items of the questionnaire that let us test the hypotheses developed. A total of 98 projects (40.8\% of total identified projects) were used in the final analysis of this study after eliminating RJVs with missing data. Thus, the level of analysis is at the project level (one company could be involved in more than one project).

\subsection{Measures}

\section{The locus of RJV}

The locus of RJV focuses on the stage of technological development at which an RJV operates. According to the main stages of technical development, the R\&D developed by RJVs could be characterized as either basic research or applied research. Each respondent was asked to reply to the question of what level they believed the research program addressed, with a "yes" or "no" for each of the categories. Yes's were coded

\footnotetext{
${ }^{4}$ All the projects are grouped within the following European programs: EU Framework Program, EUREKA Program or National Programs.
} 
with a 1, No's were coded with a 0 . Affirmative answers by RJV's placed them in groups that developed basic research. That means that the main characteristics that differentiate the locus of the RJV is the development of basic research.

\section{The knowledge management approach}

The major types of knowledge management practices used by RJVs to create collective knowledge and transform knowledge from the RJV context to a partner context are: (1) Implementation of joint research tasks; (2) Observing other partners' research facilities and practices; (3) Project meetings; (4) Informal communication among partners; (5) Undertaking similar R\&D on your own; (6) Training related to the specific cooperative R\&D activity; and (7) Codification of related information and data. The survey questions pertaining to knowledge management practices asked respondents to rank how important they were on a 1 (very low) to 5 (very high) scale. The descriptions of the factors are shown in Table 2.

In order to identify a continuous dimension for the knowledge management approach, from behavioral to techno-structural (Daft and Huber, 1987; Mirvis, 1996; Garavan, 1997; Gnyawalli and Stewart, 1999, Hansen et al 1999, Prieto, 2003). The first four knowledge management practices identified in the questionnaire (1-4 in the previous paragraph) are more related to the behavioral perspective and the last three are more related to the techno- structural perspective of knowledge management. 
Table 2. Description of learning and knowledge management practices

\begin{tabular}{ll}
\hline Practice & Description \\
\hline $\begin{array}{l}\text { Implementation of joint } \\
\text { research tasks }\end{array}$ & $\begin{array}{l}\text { Partners established joint research tasks. Research was shared among the } \\
\text { partners and knowledge was developed jointly. This way partners have } \\
\text { direct access to the RJV knowledge. }\end{array}$
\end{tabular}

Observing other partners' Visits and tours of RJVs partners' facilities and practices are research facilities and an interactive method to appreciate differences between practices partners and learn.

Project meetings

They provide the formal context for the discussion between researches of problems, new events and ongoing issues related to the $\mathrm{R} \& \mathrm{D}$ project.

Informal communication No organized interactions and more or less random among partners conversation between RJV researches about their current work. It encourages the spontaneous exchange of knowledge.

Undertaking similar R\&D Parents established non-joint research tasks. They carried out on your own parallel research and defined and created the base for an exchange of information.

Training related to the The RJV personnel attend structured sessions where they are specific cooperative $R \& D$ provided with instructional material designed to educate them activity and about subject related to the $R \& D$ project.

Codification of related These are documents written by the RJV expert that attempt information and data to capture the author expertise and insights on a subject related to the R\&D project and databases with relevant information.

Taking these definitions and categorizations into account, we revalue the ratings. Initially, we transform the reply to the questions pertaining to knowledge management practices subtracting the lowest reply to these questions for the RJV. The meaning of this newly transformed variable value is the degree to which a RJV assesses a knowledge management practice in relation to the knowledge management practice least assessed by it. This transformation is completed to avoid a general bias of higher replies by some RJVs.

Using this response result we define a behavioral management indicator as the importance that a RJV gives to this dimension of knowledge management. The indicator is created by summing the replies to the four first questions pertaining to knowledge management practices. Likewise, we define a techno-structural management indicator as the importance that a RJV gives to the other knowledge management approach. This 
second indicator is determined by summing the replies to the last three questions pertaining to knowledge management practices.

Finally, for each RJV we calculate the difference between the aggregated values of the behavioral practices and those obtained for the techno-structural ones. This difference is used as a knowledge management indicator. It assesses the RJV behavioral approach in relation to the RJV techno-structural approach. Table 3 shows the descriptive statistics of this indicator. Figure 3 displays a frequency histogram of this data which shows a good-fit to a normal distribution. The Kolmogorov-Smirnov test confirms the graphical observation.

Table 3. Statistical description of Knowledge management indicator

\begin{tabular}{|c|c|}
\hline Number of RJVs & 98 \\
\hline Minimum & -3 \\
\hline Maximum & 15 \\
\hline Average & 5.21 \\
\hline Median & 5.00 \\
\hline Standard Deviation & 3.55 \\
\hline Skweness & 0.303 \\
\hline Kurtosis & -0.084 \\
\hline
\end{tabular}

Figure 2. Histogram of the knowledge management approach indicator

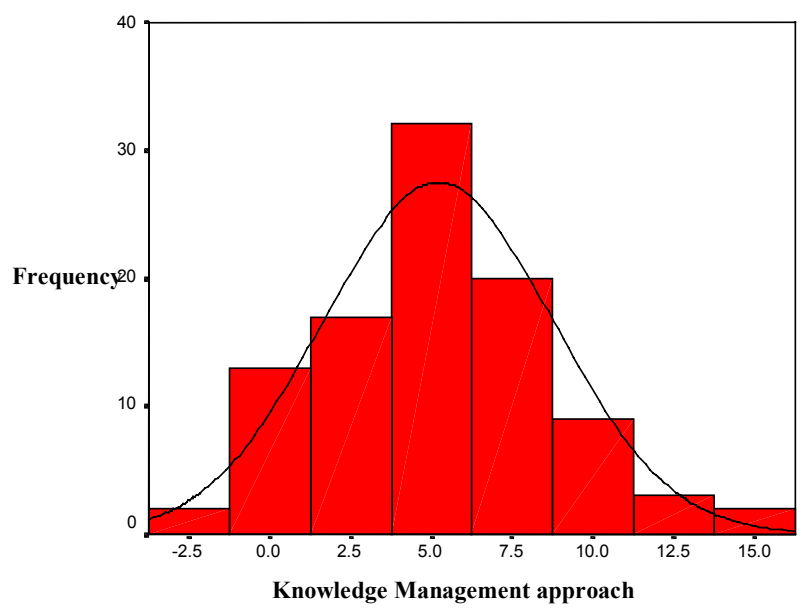




\subsection{Results}

Once the knowledge management indicator is determined the next step in our study and methodology is to determine the relationship between the locus of the RJV and the knowledge management indicator. In order to do a relationship analysis we complete two additional steps. First, we segment RJVs in our sample according to the main stages of technical development (the locus of the RJV): (1) basic research and (2) applied research. Next, the relationship between the locus of the RJV and knowledge management (Knowledge management indicator, behavioral management indicator and techno-structural management indicator) is analyzed within each category. With this aim, we apply a univariate analysis (mean, deviation, minimum and maximum value) to compute the knowledge management indicator within each type of RJV. In addition, we perform an analysis of variance (one-way ANOVA) in order to prove the statistical significance of the mean differences in knowledge management among the different categories of RJVs.

Second, we segment firms in our sample to validate the two-dimensional taxonomy of the knowledge relationship, shown in Figure 1. The four categories are obtained by using the median value as the cross section to derive a high or low knowledge management indicator. Combining this dimension with the locus of the RJV, we segment our sample using the theoretical foundations. Similar to the previous analysis, we apply a univariate analysis to compute the knowledge management indicator within each group of RJVs and perform an analysis of variance (one-way ANOVA). A Chisquared test was performed post hoc to provide a more detailed depiction of the categories. SPSS for Windows, Version 10.0 is used for data analysis.

Table 4. Impact of locus of control on Knowledge Management

\begin{tabular}{|c|c|c|c|c|c|c|c|c|c|}
\hline & \multicolumn{3}{|c|}{ Basic research } & \multicolumn{3}{c|}{ Applied research } & \multicolumn{3}{c|}{ ANOVA } \\
\hline & $\begin{array}{c}\text { Knowledge } \\
\text { Management } \\
\text { Indicator }\end{array}$ & $\begin{array}{c}\text { Behavioral } \\
\text { Perspective } \\
\text { Indicator }\end{array}$ & $\begin{array}{c}\text { Techno- } \\
\text { Structural } \\
\text { perspective } \\
\text { Indicator }\end{array}$ & $\begin{array}{l}\text { Knowledge } \\
\text { Management } \\
\text { Indicator }\end{array}$ & $\begin{array}{c}\text { Behavioral } \\
\text { perspective } \\
\text { Indicator }\end{array}$ & $\begin{array}{c}\text { Techno- } \\
\text { structural } \\
\text { perspective } \\
\text { Indicator }\end{array}$ & $\begin{array}{c}\text { Knowledge } \\
\text { Management } \\
\text { Indicator }\end{array}$ & $\begin{array}{c}\text { Behavioral } \\
\text { perspective } \\
\text { Indicator }\end{array}$ & $\begin{array}{c}\text { Techno- } \\
\text { structural } \\
\text { perspective } \\
\text { Indicator }\end{array}$ \\
\hline Mean & 3.41 & 10.24 & 6.82 & 5.59 & 11.36 & 5.77 & $\mathrm{~F}=5.551$ & $\mathrm{~F}=1.449$ & $\mathrm{~F}=3.363$ \\
\hline Deviation & 3.99 & 3.49 & 2.16 & 3.36 & 3.50 & 2.16 & & & \\
\hline Minimum & -3.00 & 5.00 & 4.00 & -2.00 & 4.00 & 3.00 & Sig. $=0.021$ & Sig. $=0.232$ & Sig. $=.070$ \\
\hline Maximum & 11.00 & 16.00 & 11.00 & 15.00 & 19.00 & 13.00 & & & \\
\hline Size & 17 & 17 & 17 & 81 & 81 & 81 & & & \\
\hline
\end{tabular}

Table 4 summarizes the results of the first analysis by including the descriptive statistics of the knowledge management indicator, behavioral management indicator and technostructural management indicator within the types of locus of the RJV and the one-way ANOVA to test differences between them.

The first and most significant observation we can make from Table 4 is that the Technostructural perspective indicator has a significantly larger mean $(\mathrm{P}<0.07)$ for basic (new) research when compared to applied research RJV characteristics. This evidence supports hypothesis H1. 
In contrast, our findings do not support our hypothesis H2. There seems to be little support for our position that RJVs with applied research characteristics show significantly greater behavioral aspects of knowledge management when compared to RJVs involved in basic research (even though the means are larger for applied research the significance is only 0.232 ). These results do point to greater alignment and mutual reinforcement of both knowledge management perspectives in RJVs with applied research characteristics. In other words, there is less difference between behavioral and techno-structural indicators for applied research.

For a deeper analysis, Table 4 provides evidence that significant differences that exist in the knowledge management indicator across locus of the control categories $(p<0.05)$. Comparisons between basic research and applied research show that basic research oriented RJVs have a lower knowledge management indicator (3.41) than applied research oriented RJVs $($ Mean $=5.59)$. These differences are true for mean values as well as for the minimum and maximum values of the knowledge management indicator. These results show that, since significant differences for the behavioral management indicator were not found when examining the locus of the RJV, differences in term of knowledge management indicator are due to the level to which RJVs employing or not employing techno-structural knowledge management.

When we segment the RJVs in our sample according to the proposed 2-dimensional classification of the RJV presented in Figure 1, we observe that the number of RJVs involved in basic research and focusing on a techno-structural approach of knowledge management are higher than the number of RJVs that develop basic research, which are concentrated on a behavioral knowledge management. Table 5 shows that $76.5 \%$ of the RJVs that are involved in basic research are in cell 2 and that only $23.5 \%$ are in cell 4 . From these observations we can argue that most basic research relies on a structural approach for knowledge management. The reason of this result could be due to the fact that basic research is more explicit, autonomous and generic than other types of R\&D projects. This result supports Jones and Handry's (1994) contention that structural or technical aspects are more related to explicit knowledge.

Table 5. Impact of a typology of RJVs with the Knowledge Management Indicator.

\begin{tabular}{|c|c|c|c|c|c|}
\hline & $\begin{array}{c}\text { Applied research/ } \\
\text { Tec.structural }\end{array}$ & $\begin{array}{l}\text { Basic research/ } \\
\text { Tec.structural }\end{array}$ & $\begin{array}{c}\text { Basic research/ } \\
\text { Behavioural }\end{array}$ & $\begin{array}{c}\text { Basic Research/ } \\
\text { Tec.structural }\end{array}$ & \multirow[t]{2}{*}{$\begin{array}{c}\text { Independence } \\
\text { test }\end{array}$} \\
\hline & Cell 1 & Cell 2 & Cell 3 & Cell 4 & \\
\hline Mean & 2.85 & 1.54 & 9.50 & 8.14 & \multirow{5}{*}{$\begin{array}{c}\text { Chi-squared } \\
4.525 \\
\text { Signif. } \\
0.003\end{array}$} \\
\hline Deviation & 1.73 & 2.15 & 1.29 & 2.32 & \\
\hline Minimum & -2.00 & -3.00 & 8.00 & 6.00 & \\
\hline Maximum & 5.00 & 5.00 & 11.00 & 15.00 & \\
\hline Size & 39 & 13 & 4 & 42 & \\
\hline
\end{tabular}

However, an analysis of the applied research does not show significant results. Only $51.8 \%$ of the RJVs that developed applied research are place on cell 3 versus $48.2 \%$ placed in cell 1 (see table 5). These findings do not support our contention that most applied RJVs are located in cell 3. These findings do support the argument that applied research is a joint outcome of techno-structural and behavioral knowledge management practices. 
The analysis of the means within Table 5 show that RJVs with applied research characteristics do not present extreme orientations in the management of their learning process. In these situations, it seems that RJVs prefer to integrate both approaches. In fact, numerous authors (Brown and Eisenhardt, 1997; Van der Krogt, 1998; Popper and Lipshitz, 1998, 2000; Choi and Lee, 2001) have recognized that knowledge management in organizations is encouraged 1) by the information mechanism and the coordination systems focused on the processing and analysis of information and 2) by the personal, social or cultural tools focused on the development of the human potential as well as on the creation of a shared meaning within organizations. The aim is that organizational members be able to expand their competencies in agreement with the guides established to optimally work in organizations.

Finally, the Chi-squared test rejects the hypothesis of independence between the locus of the RJVs and the knowledge management perspective. This observation conforms to contingency theory and corroborates the influence that the characteristics of a RJV's knowledge base, integrated in the concept of locus of the RJV, have important influence on the choices of the knowledge management practices.

Overall, the relations found between the locus of the RJV and the knowledge management indicator are limited to basic research projects, no significant relations were identified between applied research and the knowledge management relation. In terms of the taxonomy of RJVs defined in section 5 and Figure 1, we only found significant results for RJVs placed within cell 2, those that combine the development of new knowledge and techno-structural knowledge management practices. When knowledge is not novel, our RJVs sample does not follow a homogeneous behavior in terms of knowledge management. Practically, our findings suggest that both technostructural and behavioral management tools are critical to extend learning capacity.

\section{SUMMARY AND CONCLUSIONS}

In this paper we have introduced a topical area that is of growing interest to organizations, practitioners and researchers in the knowledge management field. Today many innovations that are being introduced have arisen from RJVs, it is expected that with increased complexity of technology, products and services, and the acceptance of further collaborative organizational efforts, these RJVs will only increase in popularity. Making sense and understanding knowledge management within these types of collaborations has been quite limited. This paper provides a means to help set a foundation to understand these collaborative efforts.

Using literature in the area of research joint ventures, $R \& D$, knowledge management, and organizational learning, in this study, we argued and tested the importance of certain dimensions of knowledge, integrating the locus of the R\&D as a contingency variable of knowledge management. A straightforward contingency framing is a useful first step in understanding the roles and environment of RJV knowledge management. In terms of knowledge management, the key contribution of this paper was to identify the link between the locus of the RJV and knowledge management. An understanding of how 
RJVs operate in managing their knowledge and learning processes when the locus of the RJVs is considered is beneficial to R\&D managers who need to know how to manage or structure the project for greater potential success.

Using empirical research, we show where RJVs within the given taxonomy are most effective. Thus, we found that RJVs involved in development of new knowledge tend to use a techno-structural knowledge management approach. No significant relations were identified between applied research and the knowledge management approach. For applied research the extremes of the knowledge management approach were not evident, which signifies the importance of combining both knowledge management approaches: i.e. appropriate structures, systems and procedures are needed along with personal and cultural values (Popper and Lipshitz, 1998, 2000)

A couple of limitations in this study should be noted. First, since the focus of these types of studies is on the more intangible and difficult to measure knowledge management and learning processes of the RJV, operationalization of factors and indicators to measure these dimensions is not a simple exercise. For example, discriminating factors between what is basic or applied research still need to be furthered refined and tested. Our measurement of the locus of the RJV in terms of basic research, applied research does not enable a strong discrimination for RJVs. Likewise, indicators for levels of social processes may require some proxy definitions and observations. We view this issue as complex since many times RJVs fit a spectrum of dimensions, for example what may be new to one organization may be existing knowledge to another. Second, we used attitudinal data from a single respondent (the R\&D RJV coordinator). This causes limitations since, one can argue that the R\&D coordinator is biased or does not provide an objective response, i.e. single respondent bias. The context of the study RJVs- is very specific, and carefully chosen to explain the relationship under investigation. Thus, we should be careful in generalizing these results. Thus, we see that there are limitations that exist. Operationalizing measures of the dimensions used to define the locus of RJV is the next step of our research agenda. What this contingency variable analysis can explain and what it cannot explain is something needs to be further teased out. Yet, our results do provide a means by which researchers and managers can use to help make sense of RJVs knowledge management approaches and help researchers develop a parsimonious model to evaluate $\mathrm{R} \& \mathrm{D}$ projects. 


\section{REFERENCES}

Argyris, C. and Schön, D. 1978. Organizational learning: A theory of action perspective. Addison-Wesley. Mass.

Badaracco, J.L. 1991. The knowledge link. Boston, MA: Harvard Business School Press.

Bechtold, B.L. 2000. Evolving to Organizational Learning. Hospital Material Management Quarterly, 21(3): 11-25.

Berdrow, I. and Lane, H. 2003. International joint ventures: creating value through successful knowledge management. Journal of World Business, 38:15-30

Bonaccorsi, A. and A. Piccaluga. 1994 A theoretical framework for evaluation of university-industry relationships. R\&D Management. 24( 3): 229--247.

Brown, J.S. and Duguid P. 1991. Organizational learning and communities of practice: towards a unified view of working, learning, and organization. Organizational Science, 2 (1): 40--57.

Brown, J.S., and Duguid, P. 1998. Organizing Knowledge. California Management Review. 40(3): 90-111.

Brown, S.L. and Eisenhardt, K.M. 1997. The Art of Continuous Change: Linking Complexity Theory and Time-paced Evolution in Relentlessly Shifting Organizations. Administrative Science Quarterly, 42: 1-34.

Chesbrough, H. and Teece, D.J. 1996. When is Virtual Virtuous? Organizing for innovation. Harvard Business Review, 74: 65-71.

Chesbrough, W.H., 2003. The era of open innovation. Sloan Management Review, Spring: $35-41$.

Choi, B. and Lee, H. 2002. An Empirical Investigation of KM Styles and their Effect on Corporate Performance. Information \& Management, vol. 2006. Pp. 1-15.

Cohen, W.M. and D. A. Levinthal. 1990. Absorptive capacity: A new perspective on learning and innovation. Administrative Science Quarterly, 35: 128-152.

Council on Competitiveness, 1996. Endless frontier, limited resources: U.S. R\&D policy for competitiveness. Council on Competitiveness, Washinton.

Daft, R.L. and Huber, G.P. 1987. How Organizations Learn: a Communication Framework. Research in the Sociology of Organizations, 5: 1-36.

Daft, R.L. and Lengel, R.H. 1986. Organizational Information Requirements, Media Richness and Structural Design. Management Science, 32(5): 554-571. 
DiBella, A.J. and Nevis, E. 1998. How Organizations Learn. Jossey Bass, San Francisco.

Garavan, T. 1997. The Learning Organization: A Review and Evaluation. The Learning Organization, 4(1): 18-29.

Gnyawali, D. R. 1997. Creation and Utilization of Organizational Knowledge: an Empirical Study of the Effects of Organizational Learning on Strategic Decision Making. Unpublished Doctoral Thesis, University of Pittsburgh.

Grant, R.M. 1996. Prospering in Dynamically-Competitive Environments: Organizational Capability as Knowledge Integration. Organization Science, 7(4): 375-387.

Hagedoorn, J. Link, A.N. and Vonortas, N.S. 2000. Research partnerships. Research Policy. 29: 567--586.

Hansen, M.T., Nohria, N. and Tierney, T. 1999. What's your strategy for managing knowledge. Harvard Business Review. March-April: 107-116.

Hayes, R., Wheelwright, S. and Clark, K.B. 1988. Dynamic manufacturing: Creating the learning organization. The Free Press, New York.

Hedlund, G. 1994. A Model of Knowledge Management and the N-Form Corporation. Strategic Management Journal, 15: 73-90.

Henderson, R.M. and Clark, K.B. 1990. Architectural innovation: The reconfiguration of existing product technologies and the failure of established firms. Administrative Science Quarterly 35: 9-30.

Hoopes, D.G. and Postrel, S. 1999. Shared Knowledge, "Glitches", and Product Development Performance. Strategic Management Journal, 20: 837-865.

Inkpen, G. P. 1998. Learning, knowledge acquisition, and strategic alliances. European Management Journal 16 (2): 223--229.

Inkpen, G. P. and A. Dinur. 1998. Knowledge management processes and international joint ventures. Organization Science, 9(4): 454--468.

Isaacs, W.N. 1993. Dialogue, Collective thinking, and organizational learning. Organizational Dynamics. Autumn: 24-39.

Jaikumar, R. and Bohn, R. 1986. The development of intelligent systems for industrial use: A conceptual framework. Research on Technological Innovation, Management and Policy. 3:169--211.

Kim, D.H. 1993. A framework and methodology for linking individual and organizational learning: applications in tqm and product development. Thesis Doctoral. MIT Sloan School of Management. 
Jones, A.M. and Hendry, C. 1994. The Learning Organization: Adult Learning and Organizational Transformation. British Journal of Management. 15, 153-162.

Lane, P.J., Salk, J., and Lyles, M.A., 2001. Absorptive capacity, learning, and performance in international joint ventures. Strategic Management Journal, 22, 1139-1161.

Larsson, R. Bengtsson, L. Henriksson, K.and Sparks, J. 1998. The interorganizational learning dilemma: Collective Knowledge development in strategic alliances. Organization Science. 9(3): 285--305.

March, J.G. and Simon, H.A. 1958. Organizations. Wiley, New York, NY.

McDermott, R. 1999. Why Information Technology Inspires but Cannot Deliver Knowledge Management. California Management Review, 40(4), 103-117.

Mirvis, P.H. 1996. Historical Foundations of Organizational Learning. Journal of OrganizationalChange Management, 9(1): 13-31.

Mowery, D.C. 1983. The relationship between intrafirm and contractual forms of industrial research in American manufacturing, 1900-1940. Explorations in Economic History.20. 351-374.

Nelson, R.R. 1990. U.S. Technological leadership: Where did it come from and where did it go? Research Policy, 79: 119-132.

Nonaka, I. 1994. A Dynamic Theory of Organizational Knowledge Creation. Organization Science, 5(1): 14-37.

Nonaka, I. and Takeuchi, H. 1995. The knowledge-creating company. Oxford, University Press.

Nonaka, I. Toyama, R. and Nagata, A. 2000. A firm as a knowledge-creating Entity: A new Perspective on the theory of the firm. Industrial and Corporate Change. 9 (1): $1-20$.

Pérez-López, J. 1991. Teoría de la acción humana en las organizaciones: La acción personal. Ediciones Rialp, Madrid.

Polanyi, M. 1967. The tacit dimension. Doubleday Press, Garden City, New York.

Popper, M. and Lipshitz, R. 1998. Organizational Learning: a Structural and Cultural Approach to Organizational Learning. Journal of Applied Behavioral Science, 34(2): 161179.

Popper, M. and Lipshitz, R. 2000. Organizational Learning: Mechanism, Culture, and Feasibility. Management Learning, 31(2): 181-196.

Powell, W.W., K.W. Koput, and L.Smit-Doerr. 1996. Interorganizational collaboration and the locus of innovaction: networks of learning in biotechnology. Administrative Science Quarterly, 41(1): 116-134. 
Prieto, I. 2003. Una valoración de la gestión del conocimiento para el desarrollo de la capacidad de aprendizaje de las organizaciones. Propuesta de un modelo integrador. Unpublished Doctoral Dissertation. Universidad de Valladolid, Spain.

Roussel, P.A., Saad, K.N. and Erickson, T.J. 1995. Third generation of R\&D: Managing the link to corporate strategy. Harvard Business School Press, Cambridge MA.

Schein, E.H. 1993. On Dialogue, Culture and Organizational Learning. Organizational Dynamics, 22 (2): 40-51.

Senge, P.M. 1990. The fifth discipline. Doubleday, New York.

Shrivastava, P. 1983. A typology of organizational learning systems. Journal of Management Studies. 20 (1): 7--24.

Simonin, B.L. 1999. Ambiguity and the process of knowledge transfer in strategic alliances. Strategic management Journal, 20: 595--623.

Spencer, J.C. and Grant, R.M. 1996. Knowledge and the firm: Overview. Strategic Management Journal 17, 5-9.

Subramaniam, and M. Venkatraman, N. 1999. The influence of leveraging tacit overseas knowledge for global new product development capability: an empirical examination. In: Hitt, M.A. Clifford, R.G., Nixon, R.D., Coyne, K.P. (Eds.), Dynamic strategic resources. Wiley, Chichester.

Tushman M. and Anderson, P. 1986. Technological discontinuities and organizational environments. Administrative Science Quarterly, 31: 439-465.

Von Krogh, G., Nonaka, I. and Aben, M. 2001. Making the most of your company's knowledge: A strategic Framework. Long Range Planning, 34: 421-439.

Van der Krogt, F.J. 1998. Learning Network Theory: The Tension Between Learning Systems and Work Systems in Organizations. Human Resource Development Quarterly, 9(2): 156-176.

Weick, K.E. 1991. The Nontraditional Quality of Organizational Learning. Organization Science. 2(1): 116-123.

Winter, S. 1987. Knowledge and Competence as Strategic Assets. In Teece, D. (Eds.), The Competitive Challenge. Ballinger, Cambridge, Mass. 157-184.

Zack, M.H. 1999. Developing a Knowledge Strategy. California Management Review, 41(3): 125-145. 
NOTAS

בx


NOTAS 